\title{
最近の歯学
}

\section{7. 口腔外科}

\section{ビタミンH を含さ複合凧による口内炎の治療}

\section{口腔外科学教室 志 村 介 三}

口内炎の治療には, ビタミン $\mathrm{B}_{2}, \mathrm{~B}_{6}$, ニコチン酸アミ ドなどのビタミン，コーチゾン，プレドニゾロン，ト リアムシノロン，デキサメタゾン，などの副腎皮質ホル モンが使用されており，かなりの治療効果が挙げられて いる。我々の教室では，ビオチン（ビタミンH）を含む ビタミン B 複合剤を口内炎の治療に使つて著効を得てい るので，それを紹介する。

ビオチンは牛あるいは豚の肝, 腎, 卵黄, 牛乳, 米糠, 酵母などに含まれ，Gyögyi (1931)，Kögl (1935) らによ つて抽出されたもので, 皮膚の脂肪代謝に関与して抗皮 膚炎作用があり，また細菌感染に対する抵抗作用，およ び皮膚発育促進作用がある。

ビオチンを含む複合剤にはいろいろのものがあるが， 我々の教室で使用しているのは市販名ビオビタスーS で，1 アンプル $(2 \mathrm{cc})$ 中に次ぎのものが含まれている。

$$
\begin{array}{lc}
\text { ビタミン } \mathrm{B}_{2} & 5 \mathrm{mg} \\
\text { ビタミン } \mathrm{B}_{6} & 5 \mathrm{mg} \\
\text { ニコチン酸アミド } & 20 \mathrm{mg} \\
\text { ビオチン } & 500 \gamma \\
\text { DL-メチオニン } & 40 \mathrm{mg} \\
\text { クロールフェニラミンマレアート } & 2 \mathrm{mg} \\
\text { ベンジルアルコール } & 30 \mathrm{mg}
\end{array}
$$

註：クロールフェニラミンマレアートは抗ヒスタミ ン剂

適応応は, アフタ性口内炎, 慢性再発性アフタなどを 含む潰瘍性口内炎, 接触性又はアレルギー性口内炎, 多 形㴉出性紅斑，および口角炎などで，特に再発性，およ び長期間持続性の慢性アフタに著効がある様である。然
し，前にコーチゾン系統の副腎皮質ホルモンの使用で一 度治癒した後, 再発して来たものには，あまり効果がな いようである。又，単純疮疹性口内炎，扁平紅色苔蕉な どには効果的でない。

使用法は，疾患の種類および症状によつて多少異なる が，一般的には，毎日，又は隔日に，4cc（2 アンプ ル）の筋注を続け，症状が軽快又は消失すれば $2 \mathrm{cc}(1$ アンプル）に減量して，さらに約 1 週間，これを続け る。これと併行して, 局所に刺激性の少い消毒薬の塗 布, 抗生物質その他の軟亮による被覆, スルファミン剂 または抗生剤の口腔錠の使用などを行うと, 治療効果が さらにあがる。

効果は治療を始めてから 2 3 日後に現われ，痛みな どの自覚症状がなくなり，大体 6 日前後で，他覚的に 治癒, 又は軽快する症例が多い。症状が全く消失してか らも暫くの間, ビオビタスの筋注，あるいは服薬を続け た場合には，再発を見ないか，あるいは静止期間が延長 する。又, 再発しても, 症状が軽くて済む症例が多い。 極めて著効があつた 1 例として，6年間続いた頑固なア フター性口内炎が, 本剤の注射とテトラサイクリンロ腔 錠との併用で, 約 10 日間で治癒し, その後現在までの 2 力月間再発を見ない症例を経験している。

上記の口内炎以外にも，本剤が有効なものがあるよう に思われるが，まだ治療経験が少く，確定的なことはい えないので，さらに多くの使用症例を経験し，又他の治 療法とも比較したうえで, 本剤の適応症の分析および治 療法などの詳細について発表する予定である。 